cursory' control of the ATP-requiring hexokinase is just possible. The high ADP- and $\mathrm{PO}_{4}$-concentration, at the same time, will ensure the possibilities of a quick oxidation for the substrates of respiration. The respiratory energyproduction-the oxidizing phosphorylation-thus has a free path for the intensive biosyntheses related to sprouting.

J. EIFERT

Research Laboratory of Viticulture,

A. EIFERT State Farm, Balatonboglár, Hungary.

${ }^{1}$ Winkler, A. J., and Williams, W. O., Plant Physiol., 20, 412 (1945). ${ }^{2}$ Wolf, J., in Ruhland, W., Handbuch der Pflanzenphysiologie, 6, 894 (Springer-
Verlag, 1958).

${ }^{3}$ Eifert, J., et al., Vitus, 2, 257 (1961).

- Pánczél, M., and Eifert, J., Mitteilungen, Ser. A, 10, 102 (1960).

${ }^{5}$ Geisler, G., Mitteilungen, Ser. A, 11, 1 (1961).

' Krebs, H. A., Endeavour, 16, 125 (1957).

${ }^{7}$ Rowan, K. S., et al., Nature, 177, 333 (1956)

${ }^{8}$ Turner, J. S., Ann. Rev. Plant Physiol., 2, 159 (1951).

${ }^{\circ}$ Hess, B., and Chance, B., Naturwiss., 46, 248 (1959).

${ }^{10}$ Bonner, J., Plant Biochem., 60 (Academic Press, 1950).

\section{Heat-death Temperature in Allolobophora terrestris (Sav.) forma longa (Ude) and Eisenia foetida (Sav.)}

As endeavour to deparasitize earthworms by heat in order to obtain infection-free hosts (for experimental purposes described elsewhere ${ }^{1,2}$ ) revealed an interesting difference of probable ecological significance between the two species Eisenia foetida (Sav.) and Allolobophora terrestris (Sav.) forma longa (Ude) (henceforth referred to here as Allolobophora longa).

The method of deparasitization by heat was used by Macdougall ${ }^{3}$ to kill the gregarine parasites in the larvæ of Tenebrio sp. To make use of this method with earthworms it was first necessary to determine the heat-death temperature of the worms under specific conditions. Smith ${ }^{4}$, using crude methods, observed that temperatures of $35^{\circ}-40^{\circ} \mathrm{C}$ were fatal to Allolobophora foetida Sav. ( = Eisenia foetida (Sav.)) but she did not specify the duration of exposure nor the pre-condition of the worms. Wolf ${ }^{5,6}$, using very small numbers of specimens (six per trial), determined the heat-death temperature for Lumbricus terrestris (L.) as $28^{\circ} \mathrm{C}$ for an exposure of $400 \mathrm{~min}$. In the experiments described here it was decided to determine the highest temperature which worms could survive after $12 \mathrm{~h}$ exposure (as long exposures were more likely to be offective in deparasitizing worms). The eriterion of survival adopted was 80 per cent survival in soil at room tempera. ture, $48 \mathrm{~h}$ after the end of an exposure of $12 \mathrm{~h}$ to the temperature under review. All worms used in the experiments were adult, and had been acclimatized in the same soil at a mean laboratory temperature of $15^{\circ} \mathrm{C}$ for a period of at least four weoks.

Worms were exposed to the differing temperatures by floating them individually in boiling tubes in thermostatically controlled water baths. Each tube was ballasted with clean moist gravel to make it float with the lip of the tube an inch above the water surface. Under these conditions the interior of a tube, at the surface of the gravel, attained the same temperature as the water bath in less than ten minutes after immersion. Worms were subjected to a particular temperature in batches of 20 . They were taken from well-fed laboratory cultures, and washed in water at laboratory temperature before being placed in the boiling tubes floating in the water bath. $12 \mathrm{~h}$ later the worms were removed and placed individually in soil in lidded glass dishes and then examined after a further $48 \mathrm{~h}$. Batches of 20 control worms were floated under similar conditions in water at room temperature.

In order to incorporate a confirmation procedure into the experiments (and also to shorten the total time taken) observations were made with two separate water bathsone to begin with a temperature near the lower limit for heat-death given by Wolf ${ }^{6}$ and the other to begin with a temperature near the upper limit given by Smith ${ }^{4}$. Thus one bath was maintained at $20^{\circ} \mathrm{C}$ while the other was at $38^{\circ} \mathrm{C}$ for the first trial. Specimens of both species were placed in each bath. Successive approximations were then made, using fresh batches of worms for each water bath for each trial, making the 'cool' bath hotter and the 'hot' bath cooler. After the second trial the difference between the species had become sufficiently obvious to enable them to be segregated, $E$. foetida into the 'hot' bath and $A$. longa into the 'cool' bath. Trials were continued until the criterion of survival was satisfied in each case.

In the case of $E$. foetida the critical temporature was $33 \cdot 3^{\circ} \mathrm{C}$; in the case of $A$. longa it was $25 \cdot 7^{\circ} \mathrm{C}$. This very marked difference in heat-death temperature not only points to a difference in the powers of physiological adaptation of the two species but would also explain the ability of $E$. foetida to survive the relatively high temperatures in compost heaps. It may also be associated with the habit of æstivation in the deeper soil layers, seen in A. longa in spells of hot dry weather.

Department of Zoology,

H. B. Mrles

University of Hull.

1 Miles, H. B., Nature, 195, 921 (1962).

${ }^{3}$ Miles, H. B., J. Protozool, 9 (3), 303 (1962).

${ }^{3}$ Macdougall, M. M., J. Parasit., 28, 233 (1942).

4 Smith, A. C., Amer. J. Physiol., 6, 459 (1902).

${ }^{5}$ Wolf, A. V., Ecology, 19, 346 (1938).

${ }^{6}$ Wolf, A. V., J. Cell Comp. Physiol., 18, 275 (1941).

\section{ENTOMOLOGY}

\section{Effect of Low Temperature on the Induction of Imaginal Differentiation of Dauer Pupa of the Silkworm}

IN lepidopterous insects (in which diapause occurs in the pupal stage), the pupal brain is activated by treatment by low temperature ${ }^{1-5}$. It has not yet been estab. lished, however, whother artificially diapausing, brainless pupæ (dauer pupæ) are activated by low temperature. Therefore, this question has been investigated by chilling dauer pupæ of the silkworm, Bombyx mori.

Bombyx pupæ of $F_{1}$ hybrids between two strains, J.122 and $C .115$, from the Sericultural Experiment Station, Tokyo, were used as specimens. The brain was extirpated from each individual immediately following pupation $^{6}$, and the brainless pupæ were kept for 56 days at $25^{\circ} \mathrm{C}$ following ablation.

Three groups of dauer pupæ, 56 days old, were maintained for 20,40 , and 60 days at $5^{\circ} \mathrm{C}$ respectively. Afterward, animals in each group were kept for 30 days at $25^{\circ} \mathrm{C}$. The control consisted of non-chilled dauer pupæ at the same age already mentioned which were observable for 46 days at $25^{\circ} \mathrm{C}$ following operation.

Moths did not appear in group 1 for 30 days after chilling (Table 1). However, two out of twenty-five dauer pupæ in both group 2 and 3 emerged as moths in 23-26 days following treatment, but no other animals emerged for 30 days. Moreover, of twenty-five dauer pupæ used as controls, four animals emerged as moths respectively on

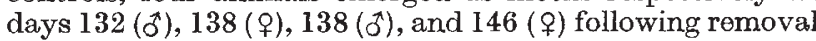
of their brains. Other animals did not show any sign of imaginal differentiation for 146 days.

After treatment with either oxygen or carbon monoxide, more than half of the dauer pupæ tested emerged as moths in 30 days following treatments? Also, when a fresh brain was implanted into each dauer pupa, the implanted animal became a moth in 18-25 days following implantation ${ }^{8}$. On the contrary, the effect of low temperature on induction of imaginal differentiation of each dauer pupa is very weak, if present at all, as demonstrated in Table 1. Moreover, as suggested in Kobayashi, 